\title{
Accommodative Intraocular Lenses
}

\author{
Felipe Soria* and Caterina Senn \\ Universidad Advenista del Plata, Argentina \\ *Corresponding author: Felipe Soria, Universidad Advenista del Plata, Argentina \\ Submission: 阱August 08, 2017; Published: 眥 September 06, 2017
}

\section{Introduction}

The goal in any surgery is to maximize the normal restoration of the anatomy and physiology of the organ or tissue involved. Knowing the procedure implied in cataract or presbyopia surgery this achievement seems totally impossible. The first registry found on accommodation is dated since the year 1609 when Steiner demonstrated for the first time that accommodation is an active process [1].

Many approaches in order to achieve a functional vision for all distances as if we had again 20 years old have been proposed an studied: Multifocal glasses [2] and contact lenses [3], Multifocal Intraocular Lenses [4-18], Lasik correction for presbyopia [19-28], Scleral Ciliary Surgery [29], corneal inlays [30-32], monovision $[33,34]$ and accommodative intraocular lenses [35,36]. In this summary a description of the accommodative intraocular lenses (AIOLs) is presented.

\section{Normal Accommodation}

Accommodation is a dynamic process in which optical changes involves modifications in the dipodic power of the eye and provides the ability to focus at different distances [37]. With the normal physiological degradation of every cell, tissue and organ, presbyopia and lens/cataract appears as something inevitable.

No system is capable to function at $100 \%$ capacity for long time. The assumption is that using only $50 \%$ of the accommodating potential will enable comfort and prolong function of the human accommodating system Donders FC [38]. In this topic, the obvious question that arises: Is there any evidence of pseudophakic accommodation available?

The capsular bag seems to be a un adequate location for AIOL's due to its unavoidable decadence and fibrosis once the crystalline lens is emptied [39]. The forces generated at the zonular anterior capsule system are those to be used for AIOL's [40]. The capsular bag is a basal membrane of the lens epithelium, once the capsular bag is emptied, there are no functions and no anatomical reasons for it to exist. The development of fibrin and atrophy is unavoidable as it has no function to accomplish and no anatomy to support [40].

\section{Accommodative Iols Lessons from the Past}

There has been a poor methodology to study near vision: Inadequate distances, non homologated near vision charts and correct artifacts in the clinical investigation. To this we can add a commercial bias, investigator's vanity in order to assure good results and poor monitorization of the investigation. The following studies that we present are examples of what was expected of AIOL and that the conclusions are determinant in terms of functionality of this type of AIOL.

A. Comparing two AIOLs with a monofocal IOL Both IOLs restored distance visual function after cataract surgery with limitations in near visual outcomes. Eyes with the dual-optic IOL had significantly better ocular optical quality [41].

B. Three-Dimensional Evaluation of Accommodating Intraocular Lens Shift and Alignment in vivo Quantitative 3-D anterior segment OCT allows full evaluation of the geometry of eyes Implanted with A-IOLs preoperatively and postoperatively [42].

Three basic approaches can be take in account for the implantation of an AIOL

1. Change in axial position Single or dual optic

2. Change in shape or curvature of residual anatomy after cataract surgery [40] The structural source of kinetic energy in the capsular bag is the anterior capsule The role of the posterior capsule is possibly minimal in accommodation and null in AIOL's The generated forces might be axial or at the frontal plane (centripetal and centrifugal)

\section{Change in refractive index or power}

\section{Conditions for a new AIOL}

A. Must be independent from the capsular bag

B. Outcomes tested by homologated opt metrical standards for near $(40 \mathrm{~cm})$ and intermediate $(70 \mathrm{~cm})$ vision 
C. Accommodation should be measured by subjective and objective tests

D. Pseudo accommodation should be identified in the outcomes

E. Outcome proved in large, multicentrical series and in long term study observation

\section{Conclusion}

Direct competitors of AIOLS are Multifocal IOLs (MFIOLs), but we must understand that mutlifocality is not physiological, besides this, mutifocality always will disperse light between the different foci, not using the $100 \%$ of it. Other issue is that multifocal optics will always require some degree of neuroadaptation. Over the coming years, once AIOLs are developed adequately, MFIOLs will be unable to compete, as it happened with pseudophakic glasses and IOLs. Let's wait and put our maximum effort in achieving the maximum satisfaction for patients in this new challenge as it has been during the history ophthalmology.

\section{References}

1. (1963) Hugh Davson: The Physiology of the Eye, $\left(2^{\text {nd }}\right.$ edn).

2. Ellison AC, Campbell AJ, Robertson MC, Sanderson GF (2014) Prismatic displacement effect of progressive multifocal glasses on reaction time and accuracy in elderly people. Clin Ophthalmol 8: 891-902.

3. Vasudevan B, Flores M, Gaib S (2014) Objective and subjective visual performance of multifocal contact lenses: Pilot study. Cont Lens Anterior Eye 37(3): 168-174.

4. Alió JL, Plaza-Puche AB, Piñero DP (2011) Optical analysis, reading performance, and quality-of-life evaluation after implantation of a diffractive multifocal intraocular lens. J Cataract Refract Surg 37(1): 2737.

5. Alió JL, Grabner G, Plaza-Puche AB (2011) Postoperative bilateral reading performance with 4 intraocular lens models: Six-month results. J Cataract Refract Surg 37(5): 842-852.

6. Alió JL, Plaza-Puche AB, Javaloy J, Ayala MJ, Moreno LJ, et al. (2012) Comparison of a new refractive multifocal intraocular lens with an inferior segmental near add and a diffractive multifocal intraocular lens. Ophthalmology 119(3): 555-563.

7. Alió JL, Piñero DP, Plaza-Puche AB, Chan MJ (2011) Visual outcomes and optical performance of a monofocal intraocular lens and a newgeneration multifocal intraocular lens. J Cataract Refract 37(2): 241-250.

8. Alió JL, Piñero DP, Plaza-Puche AB, Amparo F, Rodríguez-Prats JL, et al. (2011) Quality of life evaluation after implantation of two multifocal intraocular lens models and a monofocal model. J Cataract Refract Surg 37(4): 638-648.

9. Mesci C, Erbil HH, Olgun A, Yaylali SA (2010) Visual performances with monofocal, accommodating, and multifocal intraocular lenses in patients with unilateral cataract. Am J Ophthalmol 150(5): 609-618.

10. Muñoz G, Albarrán-Diego C, Javaloy J, Sakla HF, Cerviño A, et al. (2012) Combining zonal refractive and diffractive aspheric multifocal intraocular lenses. J Refract Surg 28(3): 174-181.

11. Bautista CP, González DC, Gómez AC (2012) Evolution of visual performance in 70 eyes implanted with the Tecnis ${ }^{\circledR}$ ZMB00 multifocal intraocular lens. Clin Ophthalmol 6: 403-407.

12. Alfonso JF, Fernández-Vega L, Blázquez JI, et al. (2012) Visual function comparison of two aspheric multifocal intraocular lenses. J Cataract Refract Surg 38(2): 242-248.
13. Dick HB (2005) Accommodative intraocular lenses: current status. Curr Opin Ophthalmol 16(1): 8-26.

14. John DF (2015) Accommodative and non-accommodative treatment of presbyopia. American Academy of Ophthalmology 1(3).

15. Alió JL, Soria F, Zein G (2014) Latest Generation Multifocal Intraocular Lenses and Emerging Accomodative Intraocular Lenses. In: Buratto L, Brint S, Bocuzzi D (Eds.), Cataract Surgery and Intraocular Lenses: SLACK Incorporated. (1 $1^{\text {st }}$ edn), pp. 177-188.

16. Gatinel D, Pagnoulle C, Houbrechts Y, Gobin L (2011) Design and qualification of diffractive trifocal optical profile for intraocular lenses. J Cataract Refract Surg 37(11): 2060-2067.

17. Alio Jorge L (2012) Top new IOL designs. Cataract \& refractive Surgery today 7(1): 62-63.

18. Alió JL, Montalbán R, Peña-García P, Soria FA, Vega-Estrada A (2013) Visual outcomes of a trifocal aspheric diffractive intraocular lens with microincision cataract surgery. J Refract Surg 29(11): 756-761.

19. Epstein D, Vinciguerra P, Frueh B (2010) Correction of presbyopia with the excimer laser. Int Ophthalmol Clin 41(2):103-111.

20. Tamayo G (2010) The dawn of presby-LASIK. Cataract \& Refractive Surgery Today Europe, pp. 64-66.

21. Pinelli R, El-Shawaf H, Caccitori D (2010) P-Curve presbyopic LASIK A new concept in refractive surgery. Cataract \& Refractive Surgery Today Europe, pp. 54-56.

22. Alió JL, Amparo F, Ortiz D, Moreno Le (2009) Corneal mutifocality with excimer laser for presbyopia correction. Curr Opin Ophthalmol 20(4): 264-271.

23. Avalos G (2006) Presbyopia treatment with LASIK PARM. In: Garg A, Hoyos J, Avalos G (Eds.), Mastering the techniques of presbyopia surgery, Jaypee, New Delhi, India, pp. 167-174.

24. Telandro A (2004) Pseudo-accommodative cornea: A new concept for correction of presbyopia. J Refract Surg 20(5): 714-717.

25. Telandro A (2009) The pseudo-accommodative cornea multifocal ablation with a center distance pattern: a review. J Refract Surg 25(1): 156-159.

26. Epstein RL, Gurgos MA (2009) Presbyopia treatment by monocular peripheral Presby LASIK. J Refract Surg 25(6): 516-523.

27. Ortiz D, Sala E, Alió JL (2009) Presbyopia correction with central pres by LASIK techniques. In: Agrawal A, Agrawal A, Jacob S (Eds.), Refractive surgery. Jaypee, New Delhi, India, pp. 274-85.

28. Illueca C, Alió JL, Mas D, Ortiz D, Pérez J, et al. (2008) Pseudo accommodation and visual acuity with Techno vision pres by LASIK and a theoretical simulated Array multifocal intraocular lens. J Refract Surg 24(4): 344-349.

29. Hamilton DR, Davidorf JM, Maloney RK (2002) Anterior ciliary sclerotomy for treatment of presbyopia: a prospective controlled study. Ophthalmology 109(11): 1970-1977.

30. Tomita M, Huseynova T (2014) Evaluating the short-term results of KAMRA inlay implantation using real-time optical coherence tomography-guided femtosecond laser technology. J Refract Surg 30(5): 326-329.

31. Abbouda A, Javaloy J, Alió JL (2014) Confocal microscopy evaluation of the corneal response following AcuFocus KAMRA inlay implantation. J Refract Surg 30(3): 172-178.

32. Huseynova T, Kanamori T, Waring GO, Tomita M (2014) Outcomes of small aperture corneal inlay implantation in patients with pseudophakia. J Refract Surg 30(2): 110-116.

33. Ito M, Shimizu K, Iida Y, Amano R (2012) Five-year clinical study of patients with pseudophakic monovision. J Cataract Refract Surg 38(8):1440-1445. 
34. Naeser K, Hjortdal JØ, Harris WF (2014) Pseudophakic monovision: optimal distribution of refractions. Acta Ophthalmol 92(3): 270-275.

35. Karavitaki AE, Pallikaris IG, Panagopoulou SI, Kounis GA, Kontadakis G, et al. (2014) Long-term visual outcomes after Crystalens ${ }^{\circledR}$ HD intraocular lens implantation. Clin Ophthalmol 8: 937-943.

36. Pérez-Merino P, Birkenfeld J, Dorronsoro C, Ortiz S, Durán S, et al. (2014) Aberrometry in patients implanted with accommodative intraocular lenses. Am J Ophthalmol 157(5): 1077-1089.

37. Kaufman P, Albert A (2010) Adler's physiology of the eye (11 th $^{\text {th }}$ dn), pp. 197-212.

38. Donders FC (1972) On the Anomalies of Accommodation and Refraction of the Eye (translated by Moore WD). Boston: Milford House Inc., USA.
39. Duane A (1912) Normal values of the amplitude of accommodation at all ages. J Am Med Assoc, pp. 1010-1013.

40. Ben-Nun J, Alió JL (2005) Feasibility and development of a high-power real accommodating intraocular lens. J Cataract Refract Surg 31(9): 1802-1808.

41. Alió JL, Plaza-Puche AB, Montalban R, Ortega P (2010) Near visual outcomes with single-optic and dual-optic accommodating intraocular lenses. J Cataract Refract Surg 38(9): 1568-1575.

42. Marcos S, Ortiz S, Pérez-Merino P, Birkenfeld J, Durán S, et al. (2014) Three-dimensional evaluation of accommodating intraocular lens shift and alignment in vivo. Ophthalmology 121(1): 45-55. 